\title{
昇温期間における東北沿岸 海面温度の変動特性 \\ VARIABILITY OF SEA SURFACE TEMPERATURE IN THE HEATING PERIOD AT THE COASTAL AREA OF THE NORTHEAST JAPAN
}

\author{
楊燦守 \\ Chan-Su YANG \\ 学生会員 工修 東北大学大学院 工学研究科土木工学専攻（T980-8579 仙台市青葉区青葉 06）
}

\begin{abstract}
The aim of this study is to analyze the variability of sea surface temperature (SST) in the month of May 1990-1994 at the Kuroshio/Oyashio frontal areas. SST variations are examined using a combination of weather conditions and offshore water-mass distribution. A series of ocean thermal imagery (37-image) from Advanced Very High Resolution Radiometer (AVHRR) are analyzed to study influence of moving fronts on the coastal thermal environment. Multiple regression analyses are used to understand the relationship between independent variables (weather variation components and offshore condition) and coastal sea surface temperature (SST) as dependent variable. The regression results provide a good correlation between the predicted value and in-situ SST. Strong impact of variation in offshore circumstances on coastal SST distribution is clearly noticed especially at the edge of warm tongues and streamers of the of the Kuroshio flowing northward.
\end{abstract}

Key Words : sea surface temperature, offshore condition, weather conditions, NOAA/AVHRR Sendai Bay, Sanriku, multiple-regression analysis

1.はじめに

一般に沿岸域はいろいろな自然的・人為的な影響 に対して敏感に応答する海域である．特に，本州の 東北沖合は黒潮, 親潮, 津軽海流が共に存在し，そ れらの相互作用は周辺の沿岸環境に大きな影響を与 えており, さらに地理的緯度が気候変動の大きいと ころにあるため, この地域の水温環境は海況と気象 変動によって大きく変化する.

黒潮/親潮前線域になる宮城県は, 海岸景観に富ん だリアス式海岸と多くの河川により，東北地域の 農・水産・商業および教育の中心地として, 古来よ り天然の良港と水運が発達してきた. 三陸の沿岸は 山地が海岸までせまっており, 湾の奥に限って小さ な平坦地がみられる。 さらに著しく狭い大陸棚のた め沖合水塊は沿岸に接近し易く, 沿岸定地水塊はし ばしば沖合の水塊の影響を受ける。三陸沿岸は親潮 の影響で, 夏に海霧の多いこと, 梅雨時に冷湿の程 度が大きいことなどが特徴であり, 年々の気候の変 動が大きく, 気象災害が起こりやすい. したがって, 本州東北方沖合の黒潮/親潮境界域は, 東北地方の冷 害や漁場環境の面からも重視されてきた ${ }^{1)}$ ，2），3). しかし, 今までの研究は外海の条件だけ考慮して行
われてきた.

一方, 楊ら ${ }^{4)}$ は昇温期の 4 月における海面温度の 変動特性解析の方法を提案し, 海水面水温 (SST) と気 象および海況との関係を調べた。 また，SST に対す る重回帰モデルでは気象要素だけを考慮して沿岸水 温予測が行った.

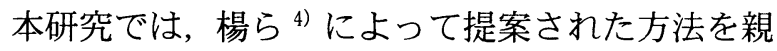
潮の影響が大きいといわれている 5 月に適用し, 海 況条件と気象要素を共に含むSST 重回帰解析と追波 湾からの河川水塊のモニタリングを行った.その際, 外洋の流況および気象変動が仙台湾周辺の水温環境 に与える影響および相互作用メカニズムを，(1)現地 観測に基づく水温と塩分変動 (90-94 年), (2)衛星画 像 (水温データ/AVHRR Ch. 4) からの海況変動 (90-94 年), (3)気象変動 (AMeDAS, 90-94 年)の三つの変動に 着目して調べた.

\section{2. 使用データと解析方法}

本研究では, 図-1 に示す仙台湾を中心に宮城県と 福島県の沿岸, および沖合を対象として考察する.

使用デー夕は, 福島県水産試験場および宮城県水 産研究開発センターによる水温と塩分のデータ, お 


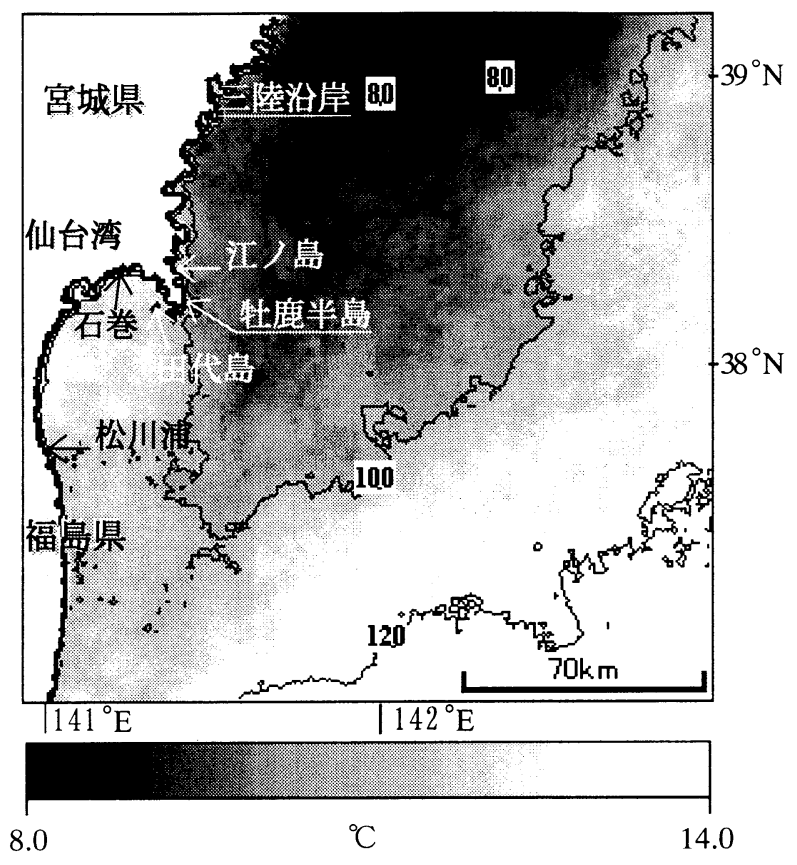

図-1 5 月の平均 SST 画像と実測点

よびAMeDAS の風, 日照時間, 降水量, 大気温度デー 夕である. 図-1 に示す石巻以外すべての場所で水温 データが得られており，田代島と江ノ島ではこれに 加えて塩分データも取得されている.

衛星データとして, 東北大学大型計算機センター の日本画像データベース (JAIDAS) から NOAA/AVHRR のチャンネル 4 (遠赤外域) デー夕を利用した。 ま ず，薄い雲の影響を取り去るため, 取得時間差が短 い画像を合成した.これらの 37 枚画像を一つの平面 二次元時系列データを作り, 水温の時系列解析を行 った.

\section{3. 三陸治岸の気象要素変動特性と沖合の海況 解析による沿岸水温環境の影響}

\section{（1）気象要素の特徵および SST と塩分の変動性との 関係}

一般に， 3 月から 8 月までは海面が暖められ， 5 月または 7 月に加熱のピークがあり, SST も 4 月と 5 月には昇温する. 図- 1 は 90 年から 94 年までの 5 月の平均水温分布図である. 水温分布特性をみると 水温の勾配が南北と東西に著しく大きく, その分布 パターンが主に黒潮と親潮によって決定されること が分かる. すなわち, 牡鹿半島南端を中心に北部の 沿岸は親潮が南部は黒潮が支配する構造を持ってい る.

5 月は 4 月と同じく昇温期間のはじめであるため, SST は日照時間（Accumulated Duration of Sunshine, 以下日照時間）とはほぼ同じ変動パターンを見せる （図-2）. 例外もあるがSST は全体的に日照時間の傾 向に従う。したがって, 図-3の T-S diagramのよう に, 江ノ島, 田代島および松川浦で水温は上昇する 傾向であり, 塩分はあまり変わらない. しかし, 三

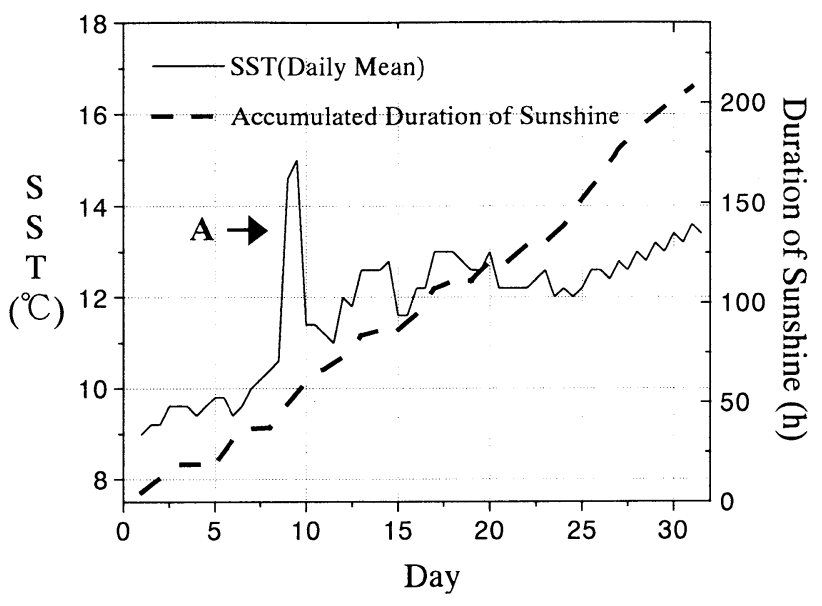

図-2 江ノ島で日照時間と SST（90 年 5 月）

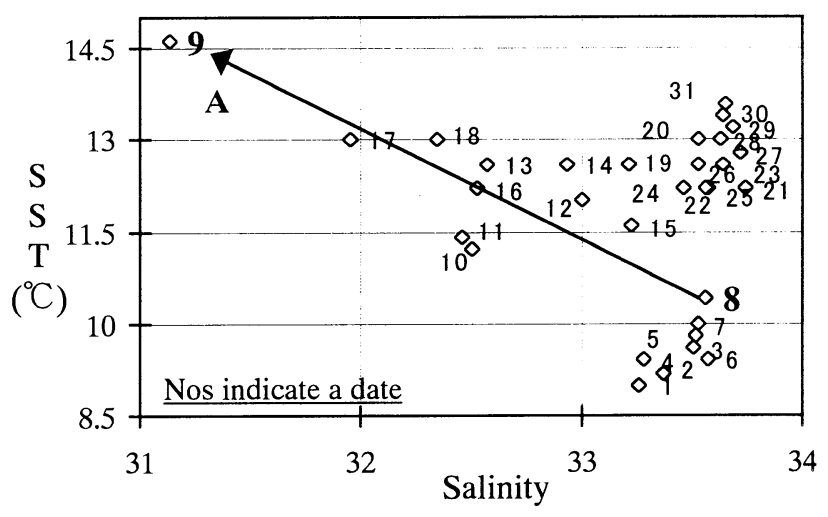

図-3 T-S diagram（江の島、90 年 5 月）
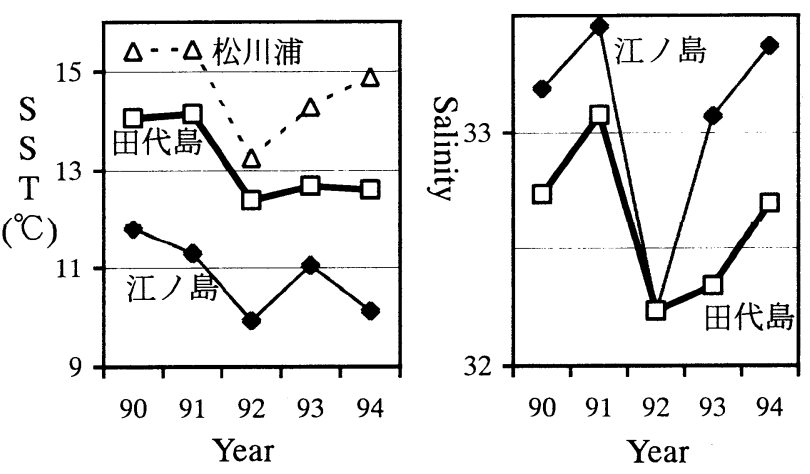

図-4 5 月の平均水温と塩分の年次変化

陸および仙台湾周辺の特徵的な地形のため, 気象要 素の変動もこの 3 つの場所で異なる.さらに, 図-1 に示したように異なる沖合水塊条件によっても, そ の SST 昇温率は大きく変動する. すなわち, 図-2 と 3 のA で示した水温のジャンプはこれらの複合作用 から起こっている例である.

図-4 は仙台湾周辺の年度別平均 SST と塩分を示す. 黒潮の影響を受けて松川浦の水温は高く, 親潮の影 響を受けて江ノ島の水温は低い，仙台湾の中の田代 島は黒潮より河川水流入の影響を受けて塩分が低い. また, 場所および年によって SST と塩分の值が大き 


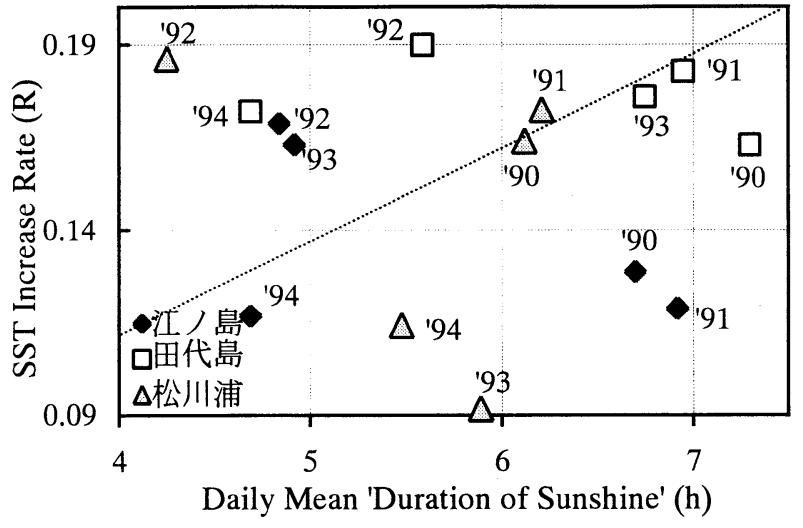

図-5 5月の日照時間と昇温率

く異なるが, それらの年変動傾向は互いに似ている. すなわち，それは沿岸熱環境に対する様々な関連要 素の中で短期間の SST 環境に及ぼす重要な共通要因 が存在することを意味している，実際，図-4 左図の 3 つ場所のような年次変動パターンを示している環 境要素として日照時間, 大気温度, 外洋条件があげ られる，それらの SST に対する寄与率については 5 章で論議する。

楊ら ${ }^{4)}$ は当海域の 4 月の水温変化に対して日射量 （短波放射）が日照時間にほぼ比例するとみて，時 間的に積分した日照時間, すなわち, 太陽からの光 エネルギーだけを考慮して SST 昇温率との関係を調 ベた. その結果, 昇温率と日照時間は線形の関係を 示すことが分かった.

5 月の場合, SST 昇温率はプラス值を持ち, 図-5 の 5 月平均昇温率線 (点線)の付近に位置することが 期待されるが 4 月と比べて広く分布している. また, 全体的に江ノ島と松川浦より田代島の昇温率が高い 特徵を持っていた. すなわち, 日照時間以外要素の 影響が大さいことを意味する. 三ヶ所全部とも 92 年 5 月は低い日照時間にもかかわらず高い昇温率を 表した. 92 年は, 海況条件が急激に変動した年であ る. 4 月はおおよそ平年の水温分布であるが 5 月初 めにも親潮の影響が大きく現れ，月末になってから 平年 5 月の分布に戻った. また, 沿岸の塩分および 気象データも他の年と比べて大きな違いを示す. 江 ノ島の場合, 塩分は 90-94 年 5 月の平均より 0.83 低い 32.2 であり, 大気温度は $1.4^{\circ} \mathrm{C}$ 低い $11.8^{\circ} \mathrm{C}$ であ った. さらに, 降水量は 92 年の総雨量, $923 \mathrm{~mm}$ の約 $20 \%$ に相当する $185 \mathrm{~mm}$ を記録した。他の二ヶ所でも 似た結果を示した. 図-5 で 92 年の分布は以上の状 況によって初めは水温上昇が抑制されたが，末期に 黒潮の影響で高い昇温率を示した.

図-6 は仙台湾沿岸の 4 地点での 5 月の風の分布を 示したものであり, 図中の括弧内の数值は平均風速 $(\mathrm{m} / \mathrm{s})$ である. 東北地方の風向は夏には南東風, 冬に は北西風が多く, 春・秋には卓越する風向がないの が普通であるといわれているが ${ }^{3)}$, 風向は地形の影 響を受けやすいので地域によってかなり異なる．風

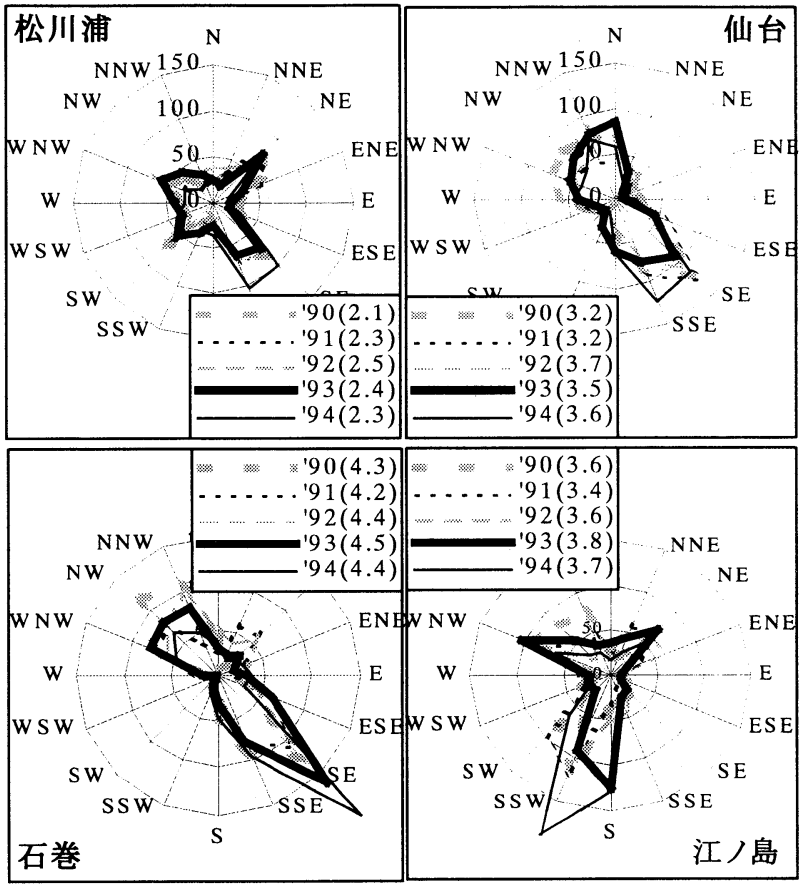

図-6 5 月の仙台湾周辺の風分布（括弧内の数值は 平均風速 $(\mathrm{m} / \mathrm{s}))$

の強さは石巻, 江ノ島, 仙台, 松川浦の順に強い. 特に, 石巻と仙台および江ノ島と平均風速は $0.7-$ $1.2 \mathrm{~m} / \mathrm{s}$ の差, 石巻と松川浦の間は $1.9-2.2 \mathrm{~m} / \mathrm{s}$ の 差があり, 地域による風特性が大きいことが分かる. しかし，4 月の場合, 風の方向はおおよそ一定であ るが，風速は年によって大きく変動した反面，5月 の同じ場所では年によって, 風の強さと方向はほと んど変わらない. また, 5 月の風分布の形状は場所 別に 4 月と殁ど同じであるがその風速は 5 月の方が 少し弱い.

江ノ島, 石巻と仙台では主に海岗線に直角の風向 きが卓越するのに対して，松川浦では風速も弱く， 特に卓越する方向もない. 西風の出現率は, 無風以 外の全観測数 (時間)に対して江ノ島で $57 \%$, 石巻で $36 \%$, 仙台で 40\%, 松川浦で 40\%である. 無風の頻度 は, 江ノ島で $2.3 \%$, 石巻で $1.6 \%$, 仙台で $3.9 \%$, 松 川浦で $11.5 \%$ ある. また, 風をべクトル分解した 結果 (北と東方向がプラス), 風の岸(南北方向)に平 行成分は, いずれの場所でもマイナス值 (90 年 5 月 江ノ島で平均 $-0.13 \mathrm{~m} / \mathrm{s}$, 石巻で平均 $-0.34 \mathrm{~m} / \mathrm{s}$, 松川 浦で平均 $-0.1 \mathrm{~m} / \mathrm{s}$ ), 直角成分の和はプラス值 (江ノ島 で平均 $1.06 \mathrm{~m} / \mathrm{s}$, 石巻で平均 $0.44 \mathrm{~m} / \mathrm{s}$, 松川浦で平均 $0.1 \mathrm{~m} / \mathrm{s}$ ) であった. すなわち, 日平均の絶対值におけ る平行成分は江ノ島で, 直角成分は石巻でもっとも 高い.このように，それぞれ地点で風速・風向に特 徵があるが, 沿岸湧昇とはあまり関係がないことが 分かった. 平均風が一番弱かった年に最も高い昇温 率を示した。

風と昇温率の関係を見るとSST と風との間にはあ まり線形的な関係がなかった。 


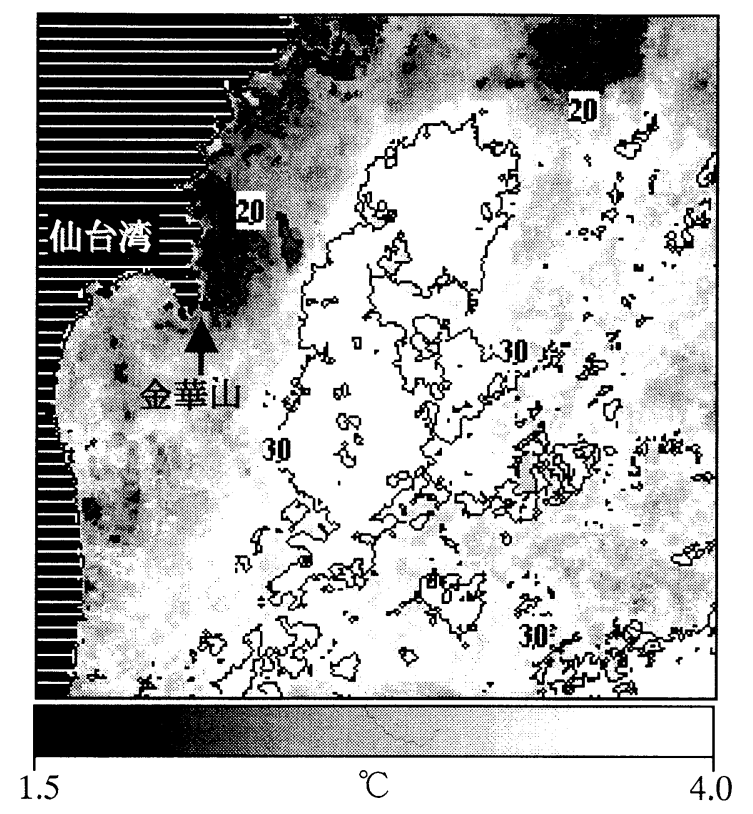

図-7 5 月の SST の標準偏差図

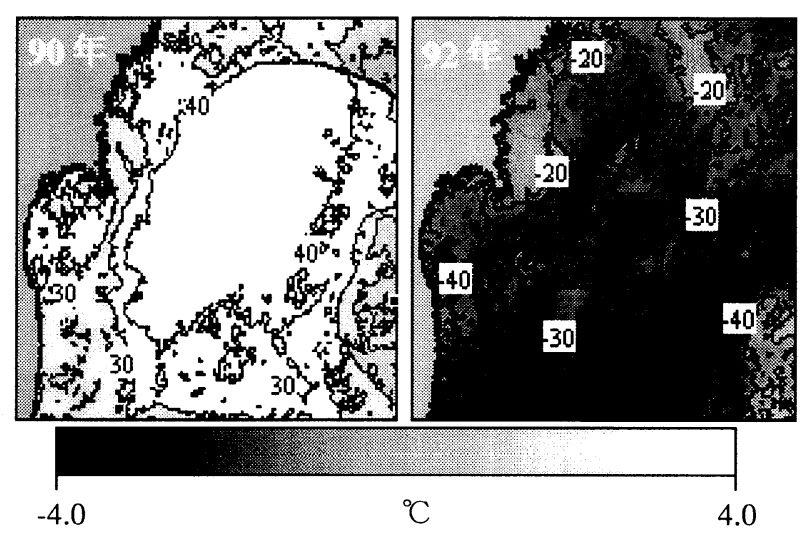

図-8 90 年と 92 年 5 月の SST Anomaly 画像

\section{(2) NOAA/AVHRR データの時系列解析}

仙台湾の内部は親潮の影響が少ない地理的特性を 持っている(図-1). Yang $5^{5),{ }^{5)}}$ は春の期間に対して 経験的固有関数解析とChlorophy 11-a 画像データか ら, 沖合の水塊が直接仙台湾の中まで影響を及ぼさ ないと判断した. 図-7 は 5 月の 37 画像に対する標 準偏差図であり，その分布範囲は 1.5-4. $0^{\circ} \mathrm{C}$ である. 三陸沿岸, 特に追波湾から牡鹿半島までの領域は $2{ }^{\circ} \mathrm{C}$ 以下で他の場所と比べてその值が小さい. すなわ ち,この域は単に親潮の影響が大きいことが分かる. また，仙台湾の中央部分は河川と大気などの直接的 な影響もあまりないので低い值を示す．図の中で仙 台湾と三陸沿岸の沖合でほぼ白い色の部分は $3.0^{\circ} \mathrm{C}$ 以上の高い標準偏差を表わしている.ここは黒潮と 親潮が交差する場所なので SST の変動性が大きい.

図-8 は 90-94 年に対して 90 年と 92 年の SST Anomaly 画像である. 90 年画像は殆どプラス偏差 (白

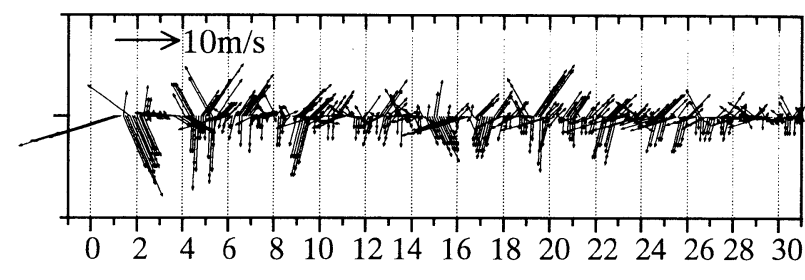

Day

図-9 江ノ島で風Vector（90 年 5 月）

色部分)を, 92 年はマイナス值を示す.これからこ の地域での黒潮・親潮の相互作用は年によっても大 きく変化することが分かる.

90 年と 91 年の 5 月は全体的に黒潮が Tongue と Streamer の形で岸近くに存在していた. そのため, 図-4から分かるように, 水温と塩分は他の年に比べ て高かった. 91 年は黒潮がCrest として北上し, 松 川浦と田代島で SST がまた江ノ島と田代島で塩分が 一番高い.

92 年には親潮が強くて福島沿岸まで影響を与え ているので，すべての沿岸で SST と塩分は最低であ る.

93 年の 5 月初めには親潮の影響がもっと強く全体 的に温度が下がったが, 半ばから黒潮が Streamer として沖合に存在し, 平年水温まで戻った.

94 年には, 沿岸には黒潮, 沖合には親潮が分布し ている.金華山までは親潮が沿岸から数十 $\mathrm{km}$ 離れて 蛇行しながら南下し, 江ノ島で低水温と高塩分の特 別な現象が起こった.

5 月は, 4 月のように年によって変動するが平均的 に仙台湾から福島県ひ沿岸, および $142^{\circ} \mathrm{E}$ の果側海 域は黒潮の影響下にあり，仙台湾の沖合から北側は 親潮の影響が大きいと判断される.

\section{4. 河ロからの水塊移動のモニタリング}

三陸沿岸一沖合の海域では，南から黒潮，北から は親潮が流れ，その間には，二つの海流から派生す る暖・冷水が入り込んで分布し，混合水域または混 乱水域と称されている。ここでは三陸沿岸で上記の 流机に便乗して移動する河川水塊による SST 環境へ の影響を調べる.

図- 2 と 3 は 90 年 5 月の江ノ島のそれぞれ SST 変 動と TS-di agram である.一般的に 5 月の TS-di agram はSST が昇温する傾向を示す。しかし，これらの図 では期待される分布よりばらばらになっており，8 日から 9 日までの急な温度増加 $\left(4.5^{\circ} \mathrm{C}\right)$ と塩分減少 (2.5) 現象が現れている. 図- 9 は江ノ島での風 Vector を示す. 江ノ島での, 4-6 日の雨量は $14 \mathrm{~mm}$, 8 日は $18 \mathrm{~mm}$ であり, 日照時間は 5 日は 0,6 日は 12.6 ,

7 日は $5.3,8$ 日は $0.5,9$ 日は 11.7 時間であり, 風 は 9 日最大 $10 \mathrm{~m} / \mathrm{s}$ WNW で前日平均より 2 倍強かった がTS-di agramの 8 日から 9 日までの急な変動の説明 は不可能である. 


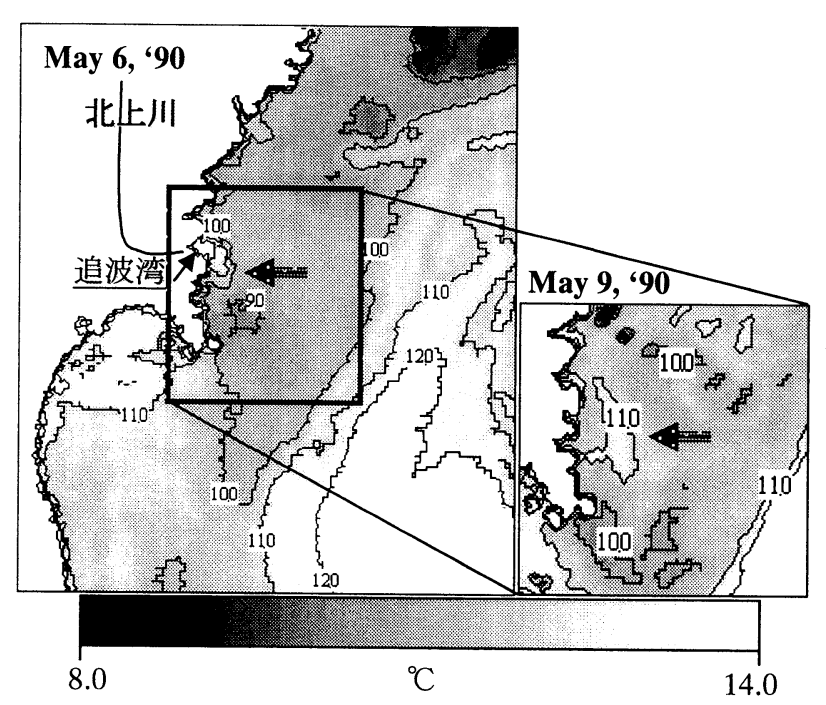

図-10 北上川からの水塊移動と水温変動

この海域に対し, NOAA/AVHRR 衛星データから 6 日 と 9 日の画像を解析した結果を図-10 に示す. 6 日の 画像には追波湾の入口から $8 \mathrm{~km}$ まで, 高い水温の水 塊が見える(図-10 の矢印部分)。またそれは南の方 向に移動し，9 日には長さ $25 \mathrm{~km}$ ，幅 $8 \mathrm{~km}$ となって江 ノ島のそばに位置していたことが分かる(図-10の 右画像の矢印部分)。すなわち, streamer 形として 北上する黒潮が右側に回って移動し，親潮はその左 側に入ってきた．それに伴って，4-6 日の降水で追 波湾から出た河川系水は，8 日の降水の補給を受け つつ，沖合の親潮南下流に引かれて，また西北西の 風に押されて，9日には金華山の北東まで移動した. その間に海面付近にレンズ状に堆積した水塊は日照 により暖められ，昇温した。10日には風が強くなり 混合されてレンズ状河川系水は希釈され，水温は低 下した。

石川と石川・中田 ${ }^{7)}{ }^{8)}$ によると追波湾は北上川の 影響を受け, 大流量の場合, 全層で 25 程度の塩分濃 度になり, 北上川の河川水は普通湾の南側に沿って 外洋へ運ばれると言う。また, 河川水により, 上層 の水温上昇と塩分濃度の低下時は一致していた。河 口から約 $30 \mathrm{~km}$ 上流の登米の河川流量記録では, 5 月 の平均流量約 $274 \mathrm{t} / \mathrm{sec}$ と較べて 6 日 $563 \mathrm{t} / \mathrm{sec}, 7$ 日 $466 \mathrm{t} / \mathrm{sec}, 8$ 日 $414 \mathrm{t} / \mathrm{sec}$ と大流量であった.

一方，5月 16-17日の間も同じような河川水の流 出が起きたが，その時の風と黒潮の条件によって江 ノ島での変動はそれほど顕著ではなかった。おそら く, 18 日から黒潮が金華山の周辺に出現し, 三陸沿 岸の南流れは止まったので，水温ジャンプが起こら なかった。

追波湾は湾入比(湾の奥行と湾口の幅の比) は約 1 2 程度であるので, 外の流れが湾の中に入りやすい 特徴を持っている. このため, 南へ移動する親潮の 流れによって, 淡水が湾の南側に沿って外洋へ運ば れると考えられる。

以上のように, AVHRR データは水塊移動の判断の
表-1 標準偏回帰係数

\begin{tabular}{|c|c|c|c|}
\hline 独立変数 & 江ノ島 & 田代島 & 松川浦 \\
\hline \hline 風の直角成分 & 0.06 & -0.21 & 0.85 \\
\hline 風の沿岸成分 & 0.02 & -1.07 & 0.13 \\
\hline 日照時間 & 4.11 & 4.27 & 2.98 \\
\hline 降水量 & 0.52 & -0.09 & 0.04 \\
\hline 大気温度 & 0.75 & 3.26 & 3.52 \\
\hline
\end{tabular}

ため, 重要な基準であることが分かる.

\section{5. 重回帰モデル}

3 章で SST 変動（図-4）と海況および気象変動と に相関関係があることが分かつた。一般に, 従属変 数 (目的変数) および独立変数 (説明変数) が量的な場 合, 予測には重回帰解析と呼ばれる手法が用いられ る.ここではSST に対する重回帰解析を用いて, 外 洋条件と大気の影響を定量的に検討する。

まず独立変数として風, 日照時間, 雨, 大気温度 を利用した．ここで風による沿岸水の移流を説明す るため, 風を沿岸 (南北方向基準)に対する直角成分 (東西) と沿岸成分 (南北)に分離し, SST デー夕取得 時間に合わせて毎日午後 3 時までの平均を取った. また，4 章で調べたように雨の影響が大きかったの で江ノ島と松川浦に対して雨の独立変数はSST と 1 日のずれを計算した. その結果, 江ノ島で重相関係 数 (MR) は 0.89 , 田代島で 0.87 , 松川浦で 0.81 と求 められた。この值は比較的に高く, 予測值は SST 実 測值をよく表現していることが分かった.

また，変数の単位が異なるため標準偏回帰係数を 求めて SST 貢献度の大きい変数を調べた(表-1)。 そ の結果, 江ノ島と田代島では日照時間が，松川浦で は大気温度がもっとも高い值を示した．江ノ島と松 川浦では風成分の影響があまりないが，田代島では 南北風が SST の降温に作用することが分かった．降 水量の影響は江ノ島で高かった. 上記のように外洋 条件がない 5 つの独立変数による SST 重回帰解析の 場合では日照時間と大気温度が重要な要素であり, 仙台湾周辺の SST 実測值をよく表現した.

次は江ノ島で沖合水塊分布を変数に変換して，6 つの説明変数から SST 重回帰モデルを求めた. 外洋 条件の独立変数は NOAA/AVHRR 衛星デー夕の水温画 像から黒潮前線を基準にして, 牡鹿半島南端の金華 山と $12^{\circ} \mathrm{C}$ 黒潮 Streamer との最短距離を求めてそ の值に ‘一’を付けて計算した.その結果を図-11 に示した。

図-11 (a) (Predicted : 予測值, In-situ : 実測值) は, 90 年 5 月の江ノ島における SST に対する重回帰 モデルに基づき求めた結果であり，予測值はSST 実 測值をよく表現した. 図-11(b)に，風の南北方向に 対する直角成分 (Wind Perpend.) と沿岸成分 (Wind Paralle l), 日照時間 (A.D.Sunshine), 雨 


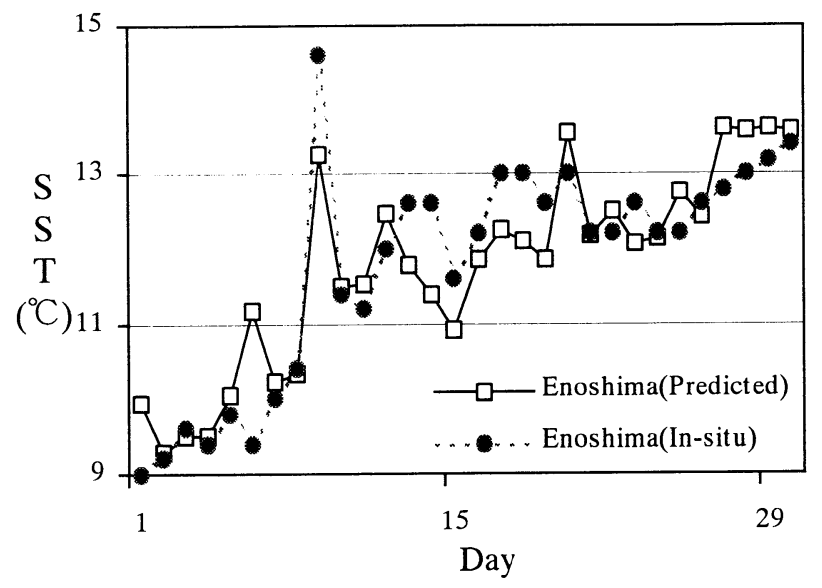

(a)

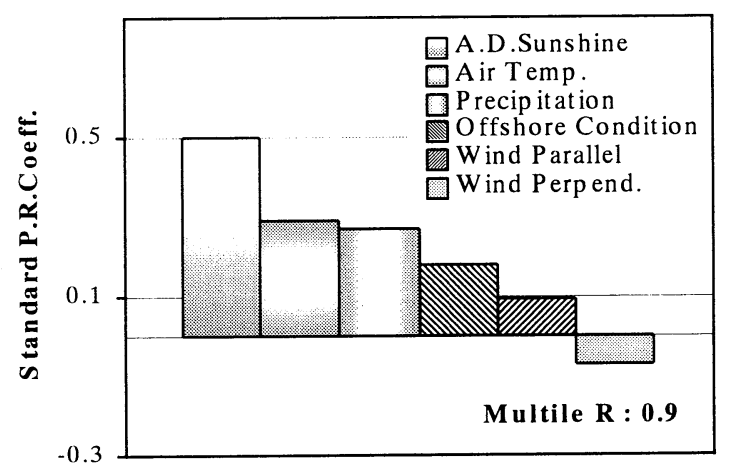

(b)

図-11重回帰モデルによる計算結果と標準偏回帰 係数

(Precipitation), 大気温度 (Air Temp.), 外洋条件 (Offshore Condition) という，6 つの説明変数に対 する標準偏回帰係数を示す. 重相関係数 (MR) は 0.90 として外洋条件がない場合より少し高く，日照時間 はSST 貢献度が一番大きい変数であることが分かっ た.また, 外洋条件の変数は 4 番目であった。図 -11 (a)で水温の急激な変化が発生した 9 日の場合, 予測 SST がピークを示した．ところが実測と予測の ピークが大きく異なる部分は SST がいろいろな要素 によって変わるためだと考えられる.

今後, 沖合海況変数の值を決める方法の改善が必 要である.

\section{6. 結論}

仙台湾周辺の三つ地点における, 日平均日照時間 とSST 昇温率との関係によると同じ日照時間に対し て昇温率は違うことが分かった. 期待される昇温率 とのずれが特に大きい年は親潮の南下が強かった 92 年である。また, すべての沿岸で SST 変動はそれ ぞれの日照時間, 大気温度, 沖合水塊条件と相関関 係があった. そして, 石巻で平均風速は他の場所よ
り 0.7-2. 2m/s の差があり, 江ノ島, 仙台, 石巻で は主に海岸線に直角の風向きが卓越するのに対し て、松川浦では平均的に卓越方向が無く風速も低か つた.すなわち、場所によって影響度合は異なるが, 沖合条件と日照時間が沿岸域の水温上昇を支配す る大きな要因であることが分かった。

三陸沿岸の追波湾から出ている北上川水塊のモ二 タリングした結果，1)湾の内部で北から南に沿岸を 沿って移動する流れの確認，2)河川水の移動による 沿岸水温環境に対する影響の平価ができた.

風(直角成分と沿岸成分), 日照時間, 雨, 大気温 度, 海況条件を独立変数とした SST 重回帰モデルで は, 重相関係数 0.81 以上として予測值は SST 実測值 をよく表現した. SST 貢献度は日照時間が一番大き かったが海況条件変数は 4 番目であった。

今後, 沖合海況変数の值を決める方法の改善およ び熱収支の計算が必要である.

謝辞 : 本研究の調査を行うに当たり, 福島県水産試 験場および宮城県水産研究開発センターから貴重な 資料を御提供頂いた. また, 東北大学大学院工学研 究科土木工学専攻沢本正樹教授, 田中仁教授, 理学 研究科地球物理学専攻花輪公雄教授に多大なるご協 力とご助言を頂いた。ここに謝意を表します.

\section{考文献}

1）工藤英郎：仙台湾に流入する沖合水について, 昭和 45 年度 IBP, PM 北方冷水海域における生物群集の生 産に関する総合的研究, 仙台湾研究班, pp. 9-26, 1971.

2）福渡渟一: 三陸沿岸海況の変動の解析, 修士論文, 東 北大学大学院土木工学専攻, pp. 10-13, 1993.

3）日本海洋学会・沿岸海洋研究部会: 日本全国沿岸海洋 誌, pp. 253-271, 1985 .

4）楊㵵守・田中仁・沢本正樹・花輪公雄 : 仙台湾周辺海 域水温環境に対する外洋・気象変動の影響に関する研 究, 海岸工学論文集, 第 46 巻, pp. 1326-1330, 1999.

5) Yang, C. S., Tanaka, H. and Sawamoto, M. : Analysis of coastal thermal environment and variability of SeaWiFS and AVHRR Imagery at the Kuroshio-Oyashio Frontal Region, Proc. '99 Int'l Conf. on Korean Scientists and Engineers, 1999. (In Press)

6) Yang, C. S., Tanaka, H., Sawamoto, M. and Hanawa, K. : Empirical orthogonal function analysis of Advanced Very High Resolution Radiometer sea surface temperature variability over the Northwest Pacific, Progress in Coastal Engineering and Oceanography, Volume 1, editor B. H. Choi, Hanrimwon Publishing Co., Korea, 1999.

7) 石川公敏・中田喜三郎：追波湾の海域特性 (I), 公害 資源研究所彙報, 9(4), pp. 35-46, 1980.

8）石川公敏:追波湾における環境変動と植物プランクト ン群構造の変化との関係, 公害資源研究所彙報, 12(2), pp. 49-62, 1982.

（1999. 9. 30 受付） 